\title{
Blood Cell Morphology, Some Hematological and Serum Biochemistry Values of Common Kestrel (Falco tinnunculus)
}

\author{
Xiaoli Shen \\ College of Animal Science and Technology \\ Shihezi University \\ Xinjiang 832003, China \\ Beijing wildlife rescue and rehabilitation Center \\ Beijing 100029, China \\ E-mail: sx12005102025@hotmail.com \\ Zhiming Zhang \\ Beijing wildlife rescue and rehabilitation Center \\ Beijing 100029, China \\ Bin Jia (Corresponding author) \\ College of Animal Science and Technology \\ Shihezi University \\ Xinjiang 832003, China \\ $\mathrm{Ya} \mathrm{Tu}$ \\ Beijing wildlife rescue and rehabilitation Center \\ Beijing 100029, China \\ Yongzhi Tian \\ College of Animal Science and Technology \\ Shihezi University \\ Xinjiang 832003, China
}

\begin{abstract}
In this study, morphological characteristics of peripheral blood cell, and certain hematological and serum biochemistry values were determined in 16 clinical healthy adult common kestrels in order to establish normal reference values for this population. Seven different types of blood cells were determined, such as erythrocytes, thrombocytes, big lymphocytes, monocytes, heterophils, basophils, small lymphocytes. According to the results, hematology of red blood cell counts, white blood cell counts, hemoglobin, packed cell volume, mean corpuscular hemoglobin (MCH), mean cell volume (MCV), mean corpuscular hemoglobin concentration (MCHC) were $2.47 \pm 0.55 \times 10^{12} / \mathrm{L}, 6.02 \pm 1.42 \times 10^{9} / \mathrm{L}$, $124.6 \pm 16.74 \mathrm{~g} / \mathrm{L}, 39.94 \pm 3.84 \%$, 523.01 $\pm 119.49 \mathrm{pg}, 523.01 \pm 119.49 \mathrm{fl}, 314.29 \pm 48.80 \%$. The results showed that serum biochemistry concentration of uric acid, total protein, albumin, alkaline phosphates were $2.22 \pm 0.68 \mathrm{nmol} / \mathrm{L}$, $6.94 \pm 0.61 \mathrm{~g} / \mathrm{L}, 4.91 \pm 0.44 \mathrm{~g} / \mathrm{L}, 10.17 \pm 2.93 \mathrm{mg} \%$. And, the different counts of leukocytes in the peripheral blood of clinical healthy common kestrel were determined as follows as $49.80 \pm 1.03 \%$ heterophils, $43.80 \pm 5.44 \%$ lymphocytes, $1.80 \pm 1.48 \%$ monocytes, $0.00 \pm 0.00 \%$ eosinophils, $3.60 \pm 1.24 \%$ basophils. These hematology and serum biochemistry values can be used as standard profiles for healthy adult common kestrel in captivity.
\end{abstract}

Keywords: Biochemistry, Common Kestrel, Hematology, Blood cell characteristic 
Campbell (1995) introduced that evaluation of avian hematologram has become a useful tool for the diagnosis of avian diseases. As the same to, hematologic and blood biochemistry analyses are valuable tools for evaluating health of wildlife, both diagnosing disease and clinical monitoring of the patient (Karesh et al., 1997. Lanzarot et al., 2001. Lanzarot et al., 2005. Toro et al., 1997. Villouta et al., 1997. Wyk et al., 1998.). However, Lanzarot et al. (2005) presumed that proper interpretation of these parameters requires appropriate reference values for each species to minimize the effect of species differences. Morphologic characteristics of avian blood cells are heterogeneous.

Common Kestrels (Falco tinnunculus) belong to the genus Falco, family Falconidae which include 13 species in the China (Zhen, 2005). They have grey with black tip and yellow cere bill (Li, 2004). They are normally distributed in Heilongjiang, Beijing, N Neimenggu, N Xinjiang (Zhen, 2005). A previous study reported morphological observation of digestive system of Common Kestrels (Niu et al, 2004).

At present, Common Kestrel is an endangered species. However, basic hematological values, morphological characteristics of peripheral blood cell and serum biochemistry values have not been described in these species. The purpose of this study is to obtain the hematology and serum biochemistry values in Common Kestrels. Knowledge of the morphological characteristics, hematological and serum biochemistry values may be applied in physiological study, health diagnosis or in-depth study directed toward their conservation.

\section{Materials and methods}

\subsection{Experimental animal}

Sixteen adult Common Kestrels (Falco tinnunculus), clinically healthy and in good condition, were kept at the Beijing wildlife rescue and rehabilitation Center. The Common Kestrels were divided into six groups of 4 animal, each group was kept in middle house $(500 \mathrm{~mm} \times 200 \mathrm{~mm} \times 600 \mathrm{~mm})$.

\subsection{Blood sampling}

Common Kestrels were restrained manually without applying sedation. All birds were examined and sampled in the nest between eight o'clock to ten o'clock AM. Each bird was handled for approximately 10 min for physical examination as described by Samour (2000), and the blood sample was obtained at the beginning of the handling period. Blood samples for the biochemical examination and the hematological profile examination were collected from the wing vein. A total $1.5 \mathrm{ml}$ of blood was collected from each of experimental animals.

\subsection{Blood cell morphology}

Blood samples for morphological characteristics of peripheral blood cell were obtained without any anticoagulant. Blood smears were immediately and air-dried. The method of Wright's stain (Bounous et al., 2000. Driver, 1981. Kuiken et al., 1999) for the basal blood cells type's characterization was used. The leukocyte differential counts were assessed by enumeration of 200-cell in each smear. Each cell type was measured and characterized.

\subsection{Hematology}

The blood from each Common Kestrel was mixed immediately in tubes with the anticoagulant natrium ethylenediaminetetraacetic acid $(1.5 \mathrm{mg} / \mathrm{dl})$. After collection, whole blood was used for the complete blood count. White blood cell counts (WBC) and red blood cell counts (RBC) were applied by an improved Neubauer hemocytometer (Brand, Wertheim, Germany) and Natt and Herrick's solution in blood cell dilution pipettes (Campbell, 1995). Packed cell volume (PCV) was tested by centrifugation at 3,000 $\times \mathrm{G}$ for $30 \mathrm{~min}$ (He et al., 2003). Hemoglobin $(\mathrm{Hb})$ content was studied by cyanide-free hemoglobin determination (Campbell, 1995). Mean cell volume (MCV), mean corpuscular hemoglobin $(\mathrm{MCH})$, and mean corpuscular hemoglobin concentration (MCHC) were calculated using the following formula (Campbell, 1995): $\mathrm{MCV}=(\mathrm{PCV} / \mathrm{RBC}) \times 10 ; \mathrm{MCH}=(\mathrm{Hb} / \mathrm{RBC}) \times 10 ; \mathrm{MCHC}=(\mathrm{Hb} / \mathrm{PVC}) \times 100$.

\subsection{Serum biochemistry}

The blood from each Common Kestrels was transferred to tubes without anticoagulant, and serum were collected by centrifugation $(3,000 \times \mathrm{G}$ for $30 \mathrm{~min})$ for biochemistry and protein electrophoresis analyses. The samples were maintained at $4-6{ }^{\circ} \mathrm{C}$ and in the dark. Blood samples were processed in the laboratory within $12 \mathrm{hr}$, and hematological analysis was investigated on the day of collection by the same person. Protein electrophoresis was performed by a spectrophotometer. Total protein (TP) was determined with the Biuret method (Lumeij et al, 1996).

\subsection{Statistical analyses}

Statistical analyses of hematologic and serum biochemical values were applied arithmetic mean, standard deviation (SD) and range.

\section{Results}

\subsection{Blood cell morphology}

Matured erythrocytes of Common Kestrels were ellipsoidal cells $(13.2 \pm 0.68 \mu \mathrm{m} \times 7.30 \pm 0.79 \mu \mathrm{m}$, Figure 1) with rounded 
poles and uniform orange-pink cytoplasm. They were centrally positioned oval nucleus $(7.27 \pm 0.59 \mu \mathrm{m} \times 3.37 \pm 0.57 \mu \mathrm{m})$ that contained dense and dark-staining chromatin. Its long diameter was parallel with long diameter of the cell.

Heterophils (Figure 2), $11.35 \pm 0.77 \mu \mathrm{m} \times 10.52 \pm 0.64 \mu \mathrm{m}$, was a single round or irregular cell with spindle or oval shaped cytoplasmic granules . They were shorter and wider than matured erythrocytes. The nucleus had $2-3$ lobules with contained dense and dark-staining chromatin. Wright solution only stained these granules slightly.

Basophiles (Figure 3), $8.7 \pm 0.71 \mu \mathrm{m} \times 8.1 \pm 0.60 \mu \mathrm{m}$, was slightly smaller than the heterophils and matured erythrocytes, their cytoplasm contained strong basophilic granules. These cells were often easily identified on Wright stained in the blood smears by the appearance of numerous, deeply basophilic, round cytoplasmic granules.

No eosinophils were identified in blood smears.

Lymphocytes had compact dark nucleus and thin cytoplasm fringe of blue color. They had two modes, which one was small lymphocyte $(8.35 \pm 0.72 \mu \mathrm{m} \times 7.77 \pm 0.73 \mu \mathrm{m}$, Figures 4$)$, other was big lymphocyte $(10.38 \pm 0.83 \mu \mathrm{m} \times 9.38 \pm 0.88 \mu \mathrm{m}$, Figures 5).

Monocytes, $12.01 \pm 0.52 \mu \mathrm{m} \times 11.03 \pm 0.82 \mu \mathrm{m}$ in diameter, were the largest leukocytes found in the blood film (Figure 6), these cells with large quadratic nuclei with pale and fine chromatin.

Thrombocytes were small oval or round cells, the nucleus was the cytoplasm colorless. Nuclei were oval with dense chromatin. When thrombocytes aggregated, they turned into round cells. The morphologic features of blood cells from Common Kestrels were similar to those of other species of avian.

\subsection{Hematology and serum biochemistry}

Results of hematology and serum biochemistry analyses are summarized in table 1

$\mathrm{WBC}=$ white blood cells. $\mathrm{RBC}=$ red blood cells. $\mathrm{PCV}=$ packed cell volume. $\mathrm{Hb}=$ hemoglobin. $\mathrm{MCV}=$ mean cell volume. $\mathrm{MCHC}=$ mean corpuscular hemoglobin concentration. $\mathrm{MCH}=$ mean corpuscular hemoglobin. $\mathrm{TP}=$ total protein; $\mathrm{AKP}$ $=$ alkaline phosphates. $\mathrm{UA}=$ uric acid. $\mathrm{AP}=$ albumin. $\mathrm{DC}=$ different white blood cells

\section{Discussions}

The first record of hematological, morphological characteristics of peripheral blood cell and serum biochemistry values of Common Kestrels are presented in this article. Sixteen adult clinically healthy Common Kestrels were studied. All birds appeared to be in good condition, and no abnormalities were noted during physical examination or in hematological analyses throughout the observation period (30 days). All indexes did not have a normal distribution. No eosinophil was identified in blood smears. Blood cell characteristics were the same to Chrysolophus pictus (Chen et al., 2007). The morphology of erythrocyte and white blood cells of Common Kestrels are showed in Figures $1-6$. Their reference intervals can be used as baseline information for further studies. It is important to use healthy animals in the establishment of reference values. However, it can be difficult to determine the health of individuals when studying field-caught wild species (Weber et al., 2002).

All blood smears in the present study were prepared immediately after venipuncture from animals, to prevent any possible effect of anticoagulant on cell morphology. Blood exposed to heparin for several hours will usually not stain as slides made immediately after collection (Walberg, 2001). Hemolytic destruction of chelonian cells by EDTA was described (Mc Arthur, 1996; Muro et al, 1998). EDTA is wildly used in avian practice; however, it is reported to cause hemolysis of blood in some avian species (Walberg, 2001).

Hematological and blood biochemistry values are widely used in avian veterinary medicine, for example, in the interpretation of laboratory results during disease. Besides, hematological and serum biochemistry values are also very important in detecting various metabolic and nutritional disorders in avian species, but it is important to have hematological data on each species in order to interpret the results accurately for a particular individual(Aengwanich $e t$ al., 2002). Hematological values are important for clinical pathological diagnosis such as traumatic injury, parasitism, organic disease, bacterial septicemia and nutritional deficiencies. Besides, anemia was defined as the presence of a below-normal red cell count, hemoglobin concentration, and/or packed cell volume, and increased mean corpuscular volume.

Total and differential leukocyte counts vary widely in avian species, probably reflecting interspecies variability and different capture, restraint, and blood collection methodologies (Padilla et al., 2003). Total white blood cell count greater than 10,000 cell/ $\mu \mathrm{l}$ was considered suggestive of leukocytosis. General causes of a leukocytosis may include infection, trauma, toxicities, hemorrhage into a body cavity, rapidly growing neoplasms and leukemia (Aengwanich $e t$ al., 2002). The mean WBC for these Common Kestrels is lower than values reported in nestling bald eagles (Bowerman et al ,2000), supposedly because of different analytic methods and interspecies variability.

The leukocyte differential aids in the assessment of the leukocytosis. Because a leukocytosis is often caused by inflammation, a heterophilia usually present. The magnitude of the heterophilia usually indicates the magnitude or 
severity of the initiating inflammatory process. Heterophils were the most numerous leukocytes in the blood of these Common Kestrels, the same as has been reported in nestling bald eagles (Bowerman et al, 2000). A leukocytosis and heterophilia can be associated with infectious agents (e.g. bacteria, fungi, chlamydia and parasites). A slight to moderate leukocytosis, heterophilia and lymphopenia can result from either an exogenous or endogenous excess of glucocorticoids (stress response). A lymphocytosis may be expected with antigenic stimulation associated with certain infections. A lymphopenia also may be expected with certain viral disease. A monocytosis can be found with certain disease that produce chemotactic agent for monocytes. These conditions include avian chlamydiosis, mycotic and bacterial granuloma and massive tissue necrosis. An eosinophilia associated with gastrointestinal nematode infections has occasionally been reported. Avian basophils are similar to mammalian basophils in their ability to produce, store and release histamine. Basophils are appeared to participate in the initial phase of the acute inflammatory response in birds, but this is not always reflected as a basophilia in the leukogram.

In this experiment, no eosinophils were identified in the blood smears, probably because the granules within avian eosinophils are water soluble and may stain poorly with Wright's stain (Bounous et al., 2000; Driver, 1981; Kuiken et al., 1999).

Mean corpuscular hemoglobin ( $\mathrm{MCH}), \mathrm{PCV}$ and $\mathrm{Hb}$ values were higher than the reference data reported by Bowerman et al (2000), supposedly due to adaptation to flight, at which the time they need for oxygen is greatly increased.

In this experiment, the concentration of the serum total protein in Common Kestrels was higher than those described for plasma in nestling bald eagles (Bowerman et al, 2000). According to Rosental (2000), protein electrophoresis is used to determine the exact blood albumin concentration, to evaluate whether a disease process is acute or chronic, and to detect whether a patient has an infection.

In this study, uric acid was different to those reported in nestling bald eagles (Bowerman et al ,2000), possibly because of different analytic methods.

Normal values for blood constituents vary widely for different species (Wyk et al., 1998). Lanzarot et al (2005) indicated that to assess the physiologic and pathologic condition of wild birds it is of paramount importance to know normal blood values for individual species. The hematologic, blood biochemistry, and the characteristic of blood cell obtained in this study for Common Kestrels will possible be useful for the interpretation of laboratory findings in future studies and clinical cases.

In this paper, the biochemical and hematological profile reported may be used as a standard profile for healthy Common Kestrels kept in captivity. Nevertheless, some differences could be expected, especially when it comes to young Common Kestrels with rapid growth and/or to adult females during the reproductive season.

\section{References}

Barahona. \& B. Maclean. (1996). Total protein determination in pigeon plasma and serum Comparison of refract metric methods with the beret method. Journal of Avian Medicine and Surgery, 10,150-152.

Bowerman, W. W., Stickle. J. E., Sikarskiei. J. G. \& Giesy, J. P. (2000). Hematology and serum chemistries of nestling bald eagles (Haliaeetus leucocephalus) in the lower peninsula of MI, USA. Chemosphere, 41, 1575-1579.

Campbell, T. W. (1995). Avian hematology and cytology (2nd). Iowa state university press, Ames, pp.104.

Bounous, Denise. I., Wyatt, Roger D., Penelope S. Gibbs, J. V. Kilburn \& Charlotte F. Quist. (2000). Normal hematology and serum biochemical reference intervals for juvenile wild Turkeys. Journal of Wildlife Diseases, 36, 393-396.

Driver, E. A. (1981). Hematological and blood chemical values of Mallard, Anas p. platyrhnchos, drakes before, during and after regime moult. Journal of Wildlife Diseases, 17, 413-421.

Karesh, W. B., Campo, A. Del., Braselton, E., Puche, H. \& Cook, R. A. (1997). Health evaluation of free-ranging and hand-reared macaws (Ara spp.) in Peru. Journal of Zoo and Wildlife Medicine, 28, 368-377.

Lanzarot, M. P., Montesinos, A., M. Andres, I. San, Rodriguez, C. \& Barahona, M. V. (2001). Hematological, protein electrophoresis and cholinesterase values of free-living nestling peregrine falcons in Spain. Journal of Wildlife Diseases, 37, 172-177.

Mcarthur. (1996). Veterinary management of tortoises and turtles. Blackwell Science, Oxford, pp170.

Lanzarot, M. Pilar, Barahona, M. Victoria, Manuel I. San Andres, Manuel Fernandez-Garcia \& Rodriguez, Casilda. (2005). Hematologic, protein electrophoresis, biochemistry, and cholinesterase values of free-living Black Stork Nestlings (Clconia Nigra). Journal of Wildlife Diseases, 41, 379-386.

Cuenca, Muro, J, Pastor, R, Vinas, J \& Lavin L. (1998). Effects of lithium heparin and tripotassium EDTA on hematologic values of hermannes tortoises (Testudo hermanni). J Zoo Wildl Med, 29, 40-44. 
Rosental, K. L. (2000). Avian complete blood count. In Laboratory medicine. Avian and exotic pets. A. M. Fudge (Ed.). W. B. Saunders, Philadelphia, Pennsylvania, pp 171-173.

Samour, J. (2000). Clinical examination. In Avian medicine, J. Samour (Ed.). Harcourt Publishers Limited, London, UK, pp 15-27.

Kuiken, Thijs, Karen L \& Danesik. (1999). Hematology and serum chemistry of captive juvenile double-crested cormorants. Can Vet J Volume, 40, 493-496.

Topo, H., VEZ, E. F., Pagough, R. E., Montes, G. \& Kaleta, E. F. (1997). Serum chemistry and antibody status to some avian pathogens of free-living and captive condors (Vultur gryphus) of central Chile. Avian Pathology, 26, 339-345.

Villouta, G., R. Hargreaves \& Riveros, V. (1997). Hematological and clinical biochemistry findings in captive Humboldt penguins (Sphenicus humboldti). Avian Pathology, 26, 851-858.

Walberg. (2001). White blood cell counting techniques in birds. Semin Avian Exotic Pet Med, 10, 72-76.

Weber, K. D., Danielson, K., Wright, S. \& Foley, J. E. (2002). Hematology and serum biochemistry values of dusky-footed wood rat (Neotoma fuscipes). Journal of Wildlife Diseases, 38, 576-582.

Aengwanich, W.,, Tanomtong, A., Pattanarungson, R. \& Simaraks, S. (2002). Blood cell characteristic, hematological and serum biochemistry values of Painted Stork (Mycteria Leucocephala). Songklanakarin J.Sci.Technol, 24, 473-479.

Wyk, E., Bank, H. \& Verdoorn, G. H. (1998). Dynamics of hematology and blood biochemistry in free-living African white backed vulture (Pseudogyps africanus) nestlings. Comparative Biochemistry and Physiology Part A, 120, 495-508.

Yu-qin Chen, Shi-yuan Yu, Zheng-xue Ma, Jing Zhang, Jian-ke Shang, Hu-lin Zhang, Ming-ren Xie, Bing-zhi Zhi, Zong-ping, Jia. \&Zhong-mei Wei. (2007). Observation on the blood cell of Chryolophus Pictus by LM and SEM. Chinese Journal of Zoology, 42(2), 107-110.

Shen-hu He, Ming-chen Wang. (2003). Commonly used lab test method of domestic animal internal medicine The Agricultural School, Ningxia University.

Xiang-tao Li. (2004). Paptors of china. Beijing: china forestry publishing house, pp 131.

Hong-xing Niu, Yan-zhen Bu, Quan-wei Lu, Qian-rui Gao. (2004). Morphologica 1 observation of digestive system of Falco Tinnunculus. J ournal of H enan N orm al U niversity ( $N$ atural S cience), 32(80), 81-83.

Guan-mei Zheng. Directory of classification and disposition for birds in china. Beijing: science publishing house, pp 42.

Table1. Hematological and blood biochemistry values of Common Kestrels

\begin{tabular}{lll}
\hline Parameter & Mean \pm SD & Range \\
AKP $\left(\mathrm{mg}^{2}\right)$ & $10.17 \pm 2.93$ & $7.69-15.23$ \\
$\mathrm{AP}(\mathrm{g} / \mathrm{L})$ & $4.91 \pm 0.44$ & $4.34-5.95$ \\
$\mathrm{DC}(\%):$ Basophils $(\%)$ & $6.94 \pm 0.61$ & $1.00-5.00$ \\
Eosinophils $(\%)$ & $0.00 \pm 0.00$ & $0.00-0.00$ \\
Heterophils $(\%)$ & $49.80 \pm 1.03$ & $42.00-55.00$ \\
Lymphocytes $(\%)$ & $43.80 \pm 5.44$ & $35.00-56.00$ \\
$\mathrm{Monocytes}(\%)$ & $1.80 \pm 1.48$ & $1.00-4.00$ \\
$\mathrm{Hb}(\mathrm{g} / \mathrm{L})$ & $2.47 \pm 0.55$ & $88-145$ \\
$\mathrm{MCH}(\mathrm{pg})$ & $523.01 \pm 119.49$ & $341.08-669.90$ \\
$\mathrm{MCV}(\mathrm{fl})$ & $169.15 \pm 44.51$ & $114.10-281.97$ \\
$\mathrm{MCHC}(\%)$ & $314.29 \pm 48.80$ & $204.36-361.11$ \\
$\mathrm{PCV}(\%)$ & $39.94 \pm 3.84$ & $32.40-45.83$ \\
$\mathrm{RBC}\left(1 \times 10^{12} / \mathrm{L}\right)$ & $2.47 \pm 0.55$ & $1.52-2.92$ \\
$\mathrm{TP}(\mathrm{g} / \mathrm{L})$ & $6.94 \pm 0.61$ & $6.00-8.30$ \\
$\mathrm{UA}(\mathrm{nmol} / \mathrm{L})$ & $2.22 \pm 0.68$ & $1.62-3.78$ \\
$\mathrm{WBC}\left(1 \times 10^{9} / \mathrm{L}\right)$ & $6.02 \pm 1.42$ & $4.25-9.75$ \\
\hline
\end{tabular}




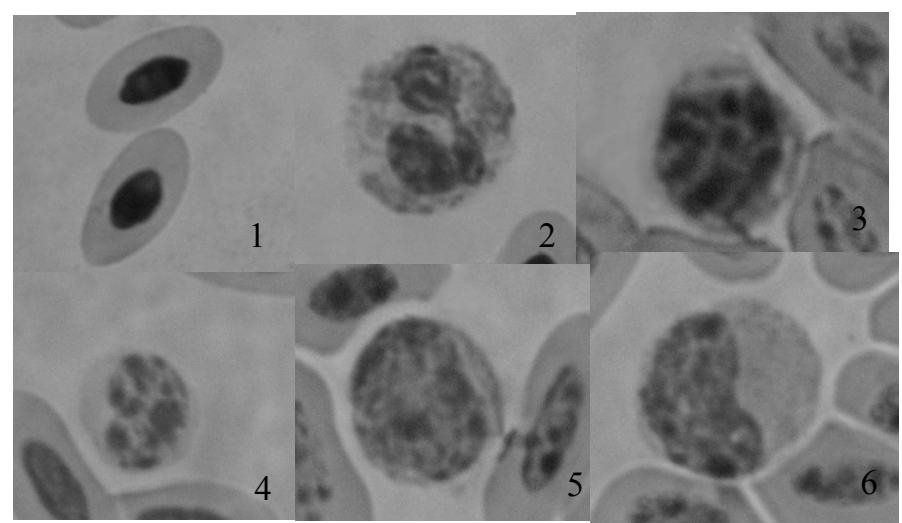

Figure 1. Matured erythrocyte. Wright's stain method $\times 1000$.

Figure 2. Heterophil. Wright's stain method $\times 1000$.

Figure 3. Basophil. Wright's stain method $\times 1000$.

Figure 4. Small lymphocyte. Wright's stain method $\times 1000$.

Figure 5. Big lymphocyte. Wright's stain method $\times 1000$.

Figure 6. Monocyte. Wright's stain method $\times 1000$. 